\title{
Effect of Furosemide on Insulin and Glucagon Responses to Arginine in Normal Subjects
}

\author{
D. Giugliano, R. Torella, S. Sgambato, and F. D'Onofrio \\ Institute of Medical Pathology and Clinical Methodology, Ist Faculty of Medicine, University of Naples, Naples, Italy
}

Summary. This study aimed at evaluating the influence of furosemide upon insulin and glucagon responses to arginine in healthy subjects. For this purpose, six normal subjects received two consecutive arginine pulses $(3 \mathrm{~g}), 60 \mathrm{~min}$ apart, before and after the administration of furosemide ( $40 \mathrm{mg}$, IV). The acute insulin response (mean change from 3-10 $\mathrm{min}$ ) to the second arginine pulse was significantly inhibited by furosemide (mean increase: 14.8 $\pm 3.0 \mu \mathrm{U} / \mathrm{ml}$ versus $11.7 \pm 2.5 \mu \mathrm{U} / \mathrm{ml}, \mathrm{p}<0.01)$. By contrast, the acute glucagon response was significantly increased (mean increase: $77 \pm 18 \mathrm{pg} / \mathrm{ml}$ versus $105 \pm 21 \mathrm{pg} / \mathrm{ml}, \mathrm{p}<0.01)$. No significant changes in plasma glucose levels occurred. In control experiments, in which saline rather than furosemide was administered, the acute insulin and glucagon response to the first arginine pulse did not differ from that observed with the second pulse. The effect of furosemide on insulin and glucagon secretion might be mediated through enhanced release of endogenous prostaglandin $\mathrm{E}$.

Key words: Furosemide, glucose, insulin, glucagon, arginine test, prostaglandins.

Soon after their introduction in clinical use in 1958 as diuretic and hypotensive agents, the benzothiadiazines seemed capable of producing a disturbance in carbohydrate metabolism similar to that of diabetes mellitus. Wilkins [1], Finnerty [2] and Freis [3] were the first to report that treatment with these agents caused hyperglycaemia in some of their hypertensive patients.

Impairment of glucose tolerance during chronic administration of thiazide preparations seems to be linked to endogenous potassium depletion [4], since Rapoport and Hurd [5] were able to return abnormal glucose tolerance to control status by replenishing potassium stores.

In previous work from this laboratory [6], intravenous furosemide significantly inhibited the acute insulin response to an IV glucose load in normal man. To our knowledge, the effect of furosemide on glucagon secretion has not been investigated.

In this report, we describe the effects of intravenous furosemide on the plasma concentration of glucose, insulin and pancreatic glucagon in response to intravenous arginine in healthy subjects.

\section{Subjects and Methods}

Twelve ( 7 males and 5 females) healthy 22 -to 40 year old subjects volunteered for our study after a clear explanation of its purpose and potential hazards. The subjects were medical students or inpatients convalescing from minor diseases, without a personal or family history of diabetes and free from metabolic or cardiovascular illness at the time of the study. The mean Ideal Body Weight, which was calculated according to the tables of the statistical bureau, Metropolitan Life Insurance Company, was 106\% (range: 94-113). All subjects were instructed to follow their usual diet and to take no drugs for at least seven days before the experiment.

All tests were done in the morning, between 0700 and $0900 \mathrm{~h}$, after an overnight fast $(12 \mathrm{~h})$. Indwelling teflon catheters were inserted in each antecubital vein, one for infusion, the other for blood sampling. Patency was preserved by a slow saline infusion $(0.154 \mathrm{~mol} / \mathrm{l})$. Three baseline specimens $(-20,-10$ and $0 \mathrm{~min})$ were obtained before starting the test and the mean of the three was used for statistical comparison. Arginine stimulation was provided by injecting intravenously $3 \mathrm{~g}(10 \mathrm{ml})$ of arginine monochloride $(30 \mathrm{~g} / 100 \mathrm{ml})$ in less than $20 \mathrm{sec}$. All subjects received two consecutive arginine pulses, 60 minutes apart. In six ( 3 male and 3 female) subjects, furosemide ( $40 \mathrm{mg}$ IV) was administered $20 \mathrm{~min}$ before the second arginine pulse. The other six (4 males and 2 females) received saline instead of furosemice and served as a control group. Blood samples were drawn at 3, 5, 8, 10, 20,30, 40,50 and $60 \mathrm{~min}$ after the first pulse and at $3,5,8,10,20,30$ and 


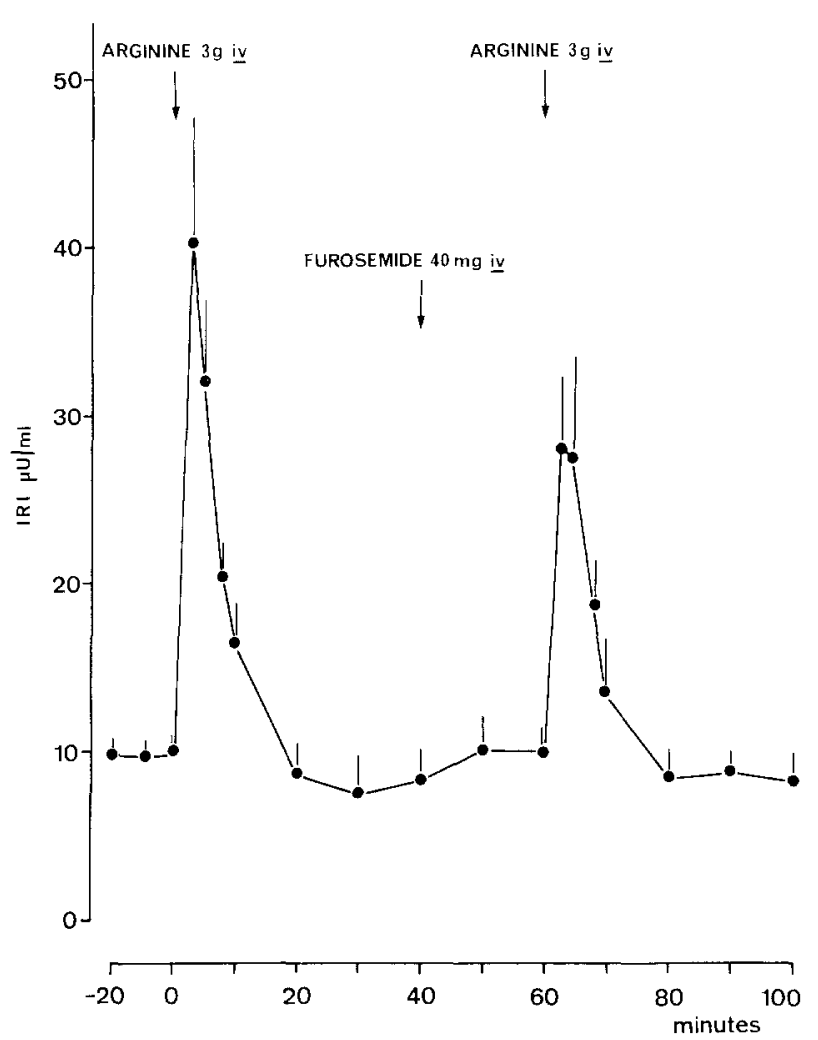

Fig. 1. Plasma insulin levels in response to arginine pulses given before and after IV administration of furosemide in six normal humans. The values are given as mean \pm SEM

$40 \mathrm{~min}$ after the second one. The Acute Insulin (AIR) and Glucagon (AGR) Responses were calculated as the mean of the 3, 5,8 and 10 minute incremental post-arginine injection values.

Blood specimens were collected in prechilled tubes containing $1.2 \mathrm{mg}$ EDTA and $500 \mathrm{U}$ Trasylol $/ \mathrm{ml}$ blood, kept in an ice-bath until the end of the study and then immediately centrifuged at $4{ }^{\circ} \mathrm{C}$. Plasma was separated and stored deep-frozen until assayed. Plasma glucose was estimated according to Huggett and Nixon [7]. Plasma insulin was measured by radioimmunoassay using dextrancoated charcoal to separate free from antibody-bound hormone [8]. For insulin values greater than $5 \mu \mathrm{U} / \mathrm{ml}$, this assay has an intraassay coefficient of variation of $10 \%$ and an interassay coefficient of $20 \%$; the minimal sensitivity of this assay using $0.1 \mathrm{ml}$ of plasma is $2 \mu \mathrm{U} / \mathrm{ml}$. Plasma glucagon was also measured by radioimmunoassay using the method of Faloona [9]. This assay has an intraassay coefficient of variation of $11 \%$ and an interassay coefficient of $20 \%$. The sensitivity limit is about $15 \mathrm{pg} / \mathrm{ml}(1.5 \mathrm{pg} /$ tube). All samples from one subject were analyzed in the same assay. Serum sodium and potassium were measured by flame photometry.

Statistical evaluation of data was performed by analysis of variance and the Wilcoxon rank-sum test.

\section{Results}

The fasting concentration of plasma glucose $(81 \pm$ $1 \mathrm{mg} / \mathrm{dl}$, range $77-85)$ insulin $(9.8 \pm 1 \mu \mathrm{U} / \mathrm{ml}$, range $4-13.5)$ and glucagon $(81 \pm 12 \mathrm{pg} / \mathrm{ml}$, range $40-115$ ) in the group receiving furosemide was not

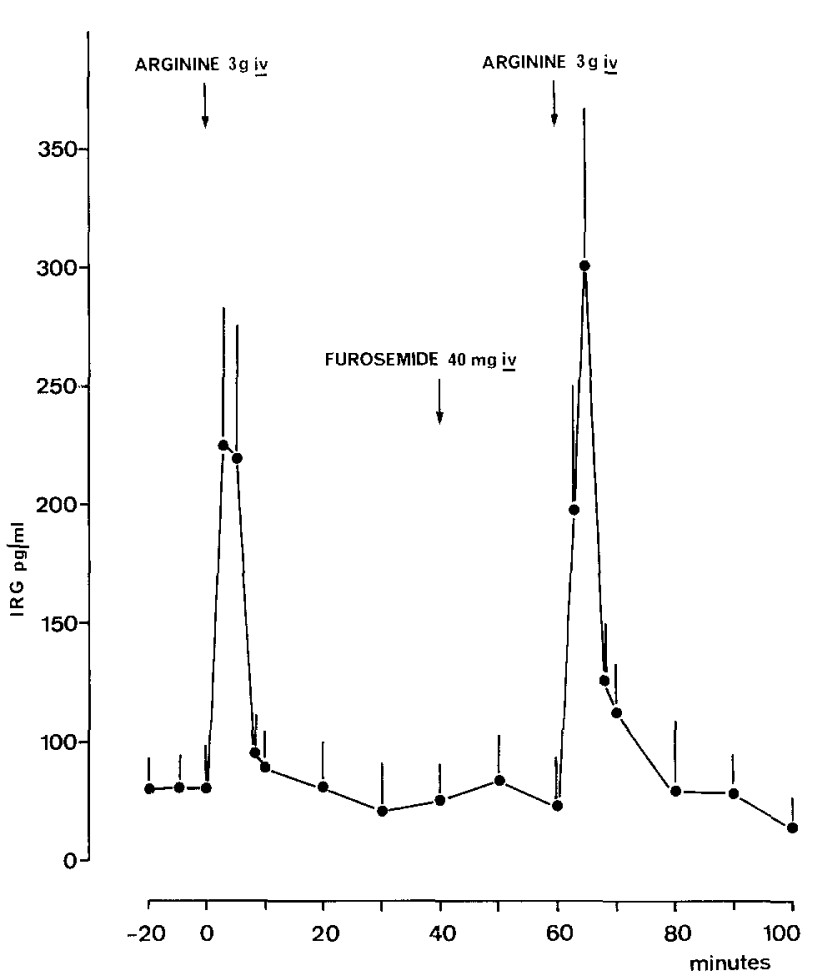

Fig. 2. Plasma glucagon levels in response to arginine pulses given before and after IV administration of furosemide in six normal humans. The values are given as mean \pm SEM

statistically different from the corresponding value obtained in the control group ( $83 \pm 4 \mathrm{mg} / \mathrm{dl}$, range $72-97 ; 8.5 \pm 1.8 \mu \mathrm{U} / \mathrm{ml}$, range $2-15 ;$ and $91 \pm$ $20 \mathrm{pg} / \mathrm{ml}$, range $45-185$, respectively).

In all subjects, there was an immediate insulin response after the initial arginine pulse; insulin returning to basal values by 20 minutes (Fig. 1). Furosemide, which was given intravenously at 40 minutes, failed to produce any immediate change in the insulin level. After the second arginine pulse, the acute insulin response was significantly less than that observed after the first arginine pulse (before furosemide: AIR $=14.8 \pm 3.0 \mu \mathrm{U} / \mathrm{ml}$; after furosemide: $\mathrm{AIR}=11.7 \pm 2.5 \mu \mathrm{U} / \mathrm{ml}, \mathrm{p}<0.01$ ).

Plasma glucagon concentration also rose promptly after the first arginine pulse and returned to basal values within 10 minutes (Fig. 2). After furosemide, the acute glucagon response to arginine was significantly higher than that observed after the first arginine injection (before furosemide: $A G R=$ $77 \pm 18 \mathrm{pg} / \mathrm{ml}$; after furosemide: AGR $=105 \pm$ $21 \mathrm{pg} / \mathrm{ml}, \mathrm{p}<0.01)$. In addition, glucagon returned to basal values more slowly after furosemide.

In control experiments, in which saline rather than furosemide was administered (Fig. 3), the acute insulin response to the first and the second arginine 
pulses was very similar (first response: $15.2 \pm$ $3.5 \mu \mathrm{U} / \mathrm{ml}$; second response: $15.7 \pm 3.6 \mu \mathrm{U} / \mathrm{ml}, \mathrm{p}=$ NS). By contrast, the increments in glucagon levels after the second arginine injection tended to be less than those observed after the first pulse (first response: $76 \pm 19 \mathrm{pg} / \mathrm{ml}$; second response: $61 \pm$ $16 \mathrm{pg} / \mathrm{ml}, \mathrm{p}=\mathrm{NS}$ ).

No significant difference was observed in plasma glucose concentration after the first and the second arginine pulse in both sets of experiments.

Serum sodium and potassium concentration did not change after furosemide.

\section{Discussion}

Our data indicate that intravenous furosemide administration significantly inhibited the acute insulin response to an intravenous arginine load whilst it increased the acute glucagon response to the same stimulus in normal subjects. The glucose response to the aminoacid was similar before and after treatment. Since none of these effects were observed without furosemide, the effects are presumably specific to the drug.

There are no reported investigations concerning the effects of furosemide upon insulin and glucagon secretion in humans. Furosemide, given for three months ( $80 \mathrm{mg}$ daily), to normal and diabetic subjects with moderate hypertension, did not cause deterioration of oral glucose tolerance or a change in glucose response to intravenous tolbutamide [10]. Two of the normal subjects, however, became diabetic after three months of therapy. Toivonen and Mustala [11] reported deterioration of oral glucose tolerance and glycosuria in one patient taking furosemide ( $80 \mathrm{mg}$ daily) for four weeks. The alterated glucose tolerance curve returned to normal two months after discontinuing administration of the drug. We previously reported that furosemide caused a clear-cut inhibition of the acute insulin response to an IV glucose load without affecting glucose tolerance [6]. Lewis et al. [12] found that glucose tolerance in non-diabetic subjects was significantly reduced only after six years of diuretic (benzothiadiazines and furosemide) treatment whereas no significant change occurred after one to three years of therapy.

The effects of furosemide on circulating insulin and glucagon levels could be ascribed to its property of stimulating prostaglandin synthesis. There are several lines of evidence in support of this hypothesis. Firstly, it has been recently reported [13] that within $10 \mathrm{~min}$ after furosemide ( $40 \mathrm{mg}$ IV) there was an immediate increase in peripheral plasma of the prostaglandin precursor, arachidonic acid; secondly, both

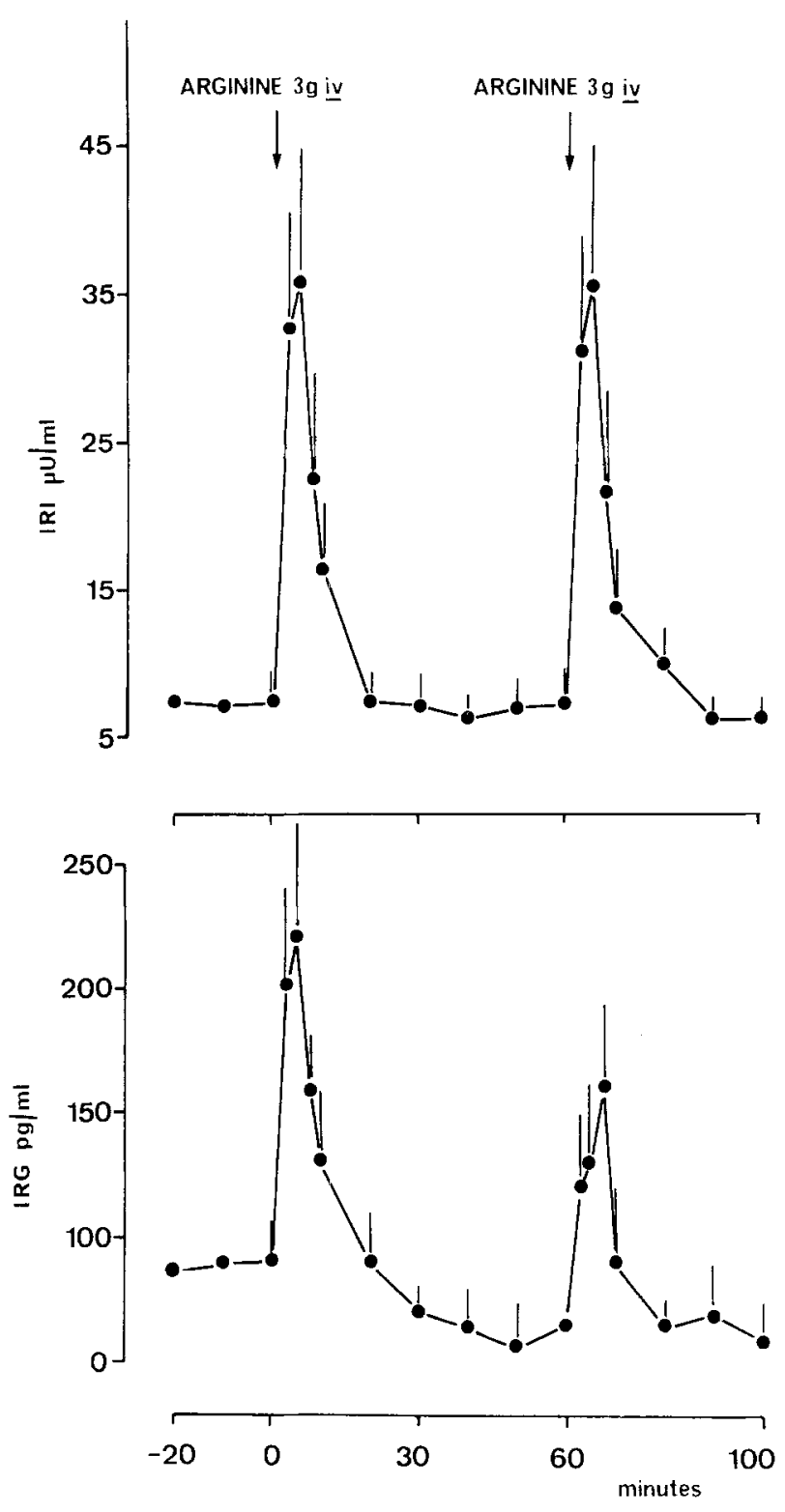

Fig. 3. Plasma insulin and glucagon levels in response to arginine pulses in six normal humans. The values are given as mean \pm SEM

prostaglandin $\mathrm{E} 1$ and prostaglandin $\mathrm{E} 2$ have been reported to inhibit the acute insulin response and glucose tolerance to an IV glucose load in a dose-dependent fashion $[14,15,16]$; thirdly, the inhibitory effect of furosemide on the acute insulin response to glucose is reversed by acetylsalicylic acid [6], an inhibitor of endogenous prostaglandin synthesis [17]; and finally, prostaglandins have been shown to stimulate glucagon secretion in vitro $[18,19]$ and in vivo $[20,21]$.

In conclusion, this study has demonstrated that furosemide inhibits the acute insulin response to arginine and also augments the acute glucagon response to this aminoacid in normal man. 


\section{References}

1. Wilkins R W (1959) New drugs for treatment of hypertension. Ann Intern Med 50: 1-10

2. Finnerty F A (1959) Discussion of special problems in therapy of hypertension. In: Moyer JF (ed) Hypertension. Saunders, Philadelphia, $\mathrm{p} 653$

3. Freis E (1959) Discussion of special problems in therapy of hypertension. In: Moyer JF (ed) Hypertension. Saunders, Philadelphia, p 790

4. Seltzer H S, Allen E W (1969) Hyperglycemia and inhibition of insulin secretion during administration of diazoxide and trichlormethiazide in man. Diabetes 18: 19-28

5. Rapoport MI, Hurd HF (1964) Thiazide-induced glucose intolerance treated with potassium. Arch Intern Med 113: $405-409$

6. Giugliano D, Torella R, Sgambato S, D'Onofrio F (1979) Acetylsalicylic acid restores acute insulin response reduced by furosemide in man. Diabetes 28: 841-45

7. Huggett A SG, Nixon D A (1957) Use of glucose-oxidase, peroxidase and o-dianisidine in the determination of blood and urinary glucose. Lancet II: $368-370$

8. Herbert V, Lan K S, Gottlieb CW, Bleicher S J (1965) Coated charcoal immunoassay of insulin. J Clin Endocrinol Metab 25: $1375-1380$

9. Faloona GR, Unger RH (1974) Glucagon. Methods of hormone radioimmunoassay. Academic Press, New York, p $317-330$

10. Jackson W P U, Nellen M (1966) Effect of frusemide on carbohydrate metabolism, blood pressure and other modalities: a comparison with chlorothiazide. Br Med J II: 333-336

11. Toivonen S, Mustala O (1966) Diabetogenic action of frusemide. Br Med J I: 920-921

12. Lewis P J, Konher EM, Petrie A, Dollery C T (1976) Deterioration of glucose tolerance in hypertensive patients on prolonged diuretic treatment. Lancet I: 564-566
13. Weber P C, Scherer B, Larsson C (1977) Increase of free arachidonic acid by furosemide in man as the cause of prostaglandin and renin release. Eur J Pharmacol 41: 329-332

14. Giugliano D, Torella R, Improta L, D'Onofrio F (1978) Effects of prostaglandin E1 and prostaglandin F-2a on insulin and glucagon circulating levels during the intravenous glucose tolerance test in man. Diabete Metab 4: 187-191

15. Giugliano D, Torella R (1978) Prostaglandin E-1 inhibits glucose-induced insulin secretion in man. Prostaglandins Med 1: 165-166

16. Robertson R P, Chen M (1977) A role for prostaglandin $E$ in defective insulin secretion and carbohydrate intolerance in diabetes mellitus. J Clin Invest 60: 747-753

17. Hamberg M (1972) Inhibition of prostaglandin synthesis in man. Biochem Biophys Res Commun 49: 720-725

18. Pek S, Tai TY, Elster A (1978) Stimulatory effects of prostaglandins E-1, E-2 and F-2 a on glucagon and insulin release in vitro. Diabetes 27: 801-809

19. Luyckx A S, Lefebvre PJ (1978) Possible role of endogenous prostaglandins in glucagon secretion by isolated guinea-pig islets. Diabetologia 15: 411-416

20. Saccà L, Perez G (1976) Influence of prostaglandins on plasma glucagon levels in the rat. Matebolism 25: 127-130

21. Giugliano D, Torella R, Sgambato S, D'Onofrio F (1978) Prostaglandin E-1 increases basal glucagon in man. Pharmacol Res Commun 10: 813-821

Received: May 8, 1979, and in revised form: November 1, 1979

Dr. Dario Giugliano

Istituto di Patologia Medica

Piazza L. Miraglia

I-80138 Napoli

Italy 